\title{
KINERJA EFISIENSI ENERGI TERHADAP MANAJEMEN BIAYA OPERASIONAL GEDUNG
}

\author{
Dano Quinta Revana ${ }^{1}$, Wisnumurti ${ }^{2}$ dan Agung Murti Nugroho ${ }^{3}$ \\ 1 Mahasiswa, Program Magister, Jurusan Teknik Sipil, Fakultas Teknik, Universitas \\ Brawijaya \\ 2 Dosen, Jurusan Teknik Sipil, Fakultas Teknik, Universitas Brawijaya \\ 3 Dosen, Jurusan Arsitektur, Fakultas Teknik, Universitas Brawijaya \\ Korespondensi: revanareeree@gmail.com
}

\begin{abstract}
The concept of Green Building is one of the efforts to reduce the effects of global warming through developmental aspects. Excessive energy consumption becomes an issue of global warming and waste of operational cost in the building so that this research will conduct an assessment using GREENSHIP and SNI parameters in Building E Faculty of Administration Brawijaya University expected to know the level of "green" in energy efficiency criteria. Energy Consumption Intensity in this building is 60,65 $\mathrm{kWH/} \mathrm{m} / \mathrm{year}$. Some rooms have the use of electric power exceeding the maximum SNI power, so there needs to be a reduction of wattage bulbs and lamp replacements with LED lights that can save power 2.039,04 $\mathrm{kWH}$ and saving the operational cost Rp. 1.935.218,88 every month.
\end{abstract}

Keywords : cost energy, operational cost management, energy efficiency, green building

\section{PENDAHULUAN}

Masa modern saat ini kebutuhan energi sangatlah dibutuhkan untuk melakukan aktivitas sehari-hari dan cenderung tidak dapat ditinggalkan yaitu kebutuhan energi listrik. Penggunaan akan kebutuhan energi terus bertambah seiring bertambahnya penduduk yang semakin cepat setiap tahunnya. Energi listrik merupakan sumber energi utama untuk memenuhi kebutuhan energi dunia yang tidak dapat diperbaharui. Jika belum ada pengelolaan yang baik dan belum memulai penghematan dalam penggunaan maka semakin hari akan semakin berkurang dan tidak menutup kemungkinan akan habis. Pembangunan gedung berkembang pesat tidak hanya untuk hunian, namun banyak dibangunnya gedung untuk keperluan umum, bersamaan dengan pembangunan gedung yang pesat maka tingkat pemanasan global pun semakin meningkat. Permasalahan ini merupakan hal yang serius untuk ditanggapi, karena berdampak terhadap keberlangsungan hidup manusia.
Malang merupakan kota pendidikan yang memiliki beberapa universitas. Universitas Brawijaya merupakan salah satu perguruan tinggi yang paling banyak diminati di Malang. Saat ini Universitas Brawijaya pun mantap dengan green campus pada tahun 2017. Dengan adanya wacana green campus, dapat di maksimalkan lagi dengan menerapkan pada bangunan melalui bangunan hijau atau Green Building. Konsep Green Building merupakan salah satu upaya untuk mengurangi efek dari pemanasan global melalui segi pembangunan dengan cara penghematan energi di mulai dari perancangan, pelaksanaan konstruksi, sampai gedung beroperasi. Dengan konsep tersebut pengelola gedung pun dapat merasakan langsung manfaatnya yaitu rendahnya biaya operasional sebagai akibat dari efisiensi dalam pemanfaatan energi.

Konsumsi energi berlebih menjadi isu pemanasan global dan pemborosan biaya operasional pada gedung sehingga penelitian ini nantinya akan melakukan penilaian menggunakan parameter GREENSHIP 
diharapkan dapat mengetahui tingkatan "green" pada bangunan dalam kinerja efisiensi energi dan menghitung biaya operasional eksisting secara teoritis untuk mengetahui langkah manajemen biaya selanjutnya sampai menghasilkan upaya-upaya penghematan energi. Permasalahan yang akan dibahas adalah kesesuaian penilaian kriteria aspek Energy Efficiency and Conservation, pengaruh kinerja nya terhadap manajemen.

\section{TINJAUAN PUSTAKA}

\subsection{Manajemen Konstruksi}

Manajemen konstruksi ini juga merupakan suatu organisasi yang mengkhususkan diri dalam mempraktekkan pada suatu proyek tertentu, sebagai bagian dari tim manajemen proyek. Pekerjaan sebuah proyek konstruksi selalu dimulai dengan tiga hal, yaitu penyusunan perencanaan, penyusunan jadwal, dan pengendalian untuk mendapatkan hasil yang sesuai dengan rencana. Dalam proses mencapai tujuan tersebut terdapat tiga aspek pokok, yaitu besarnya biaya anggaran yang dialokasikan, jadwal kegiatan, dan mutu yang harus dipenuhi untuk mencapai suatu keberhasilan proyek [1].

\subsection{Bangunan Gedung}

Pedoman pemeliharaan dan perawatan bangunan gedung menurut Peraturan Menteri Pekerjaan Umum Nomor : 24/PRT/M/2008, bangunan gedung adalah wujud fisik hasil pekerjaan konstruksi yang menyatu dengan tempat kedudukannya, sebagian atau seluruhnya berada di atas dan/atau di dalam tanah dan/atau air, yang berfungsi sebagai tempat manusia melakukan kegiatannya, baik untuk hunian atu tempat tinggal, kegiatan keagamaan, kegitan usaha, kegiatan sosial, budaya, maupun kegiatan khusus. Bangunan fasilitas pendidikan merupakan bangunan yang difungsikan sebagai sarana pendidikan, di mana aktifitas utama di dalamnya adalah belajar. Macam bangunan pendidikan misalnya sekolah, universitas, perpustakaan, sanggar, dan laboratorium

\subsection{Manajemen Operasional Gedung}

Manajemen operasional bertujuan memberikan suatu panduan dalam menjalankan operasional gedung, dimana hal-hal yang perlu diperhatikan terebut adalah sebagai berikut : a. Ada pemeriksaan dan monitoring jadwal perawatan berkala dan menyusun rencana kerja setiap bulan.

b. Penyusunan jadwal pengoperasian secara rinci dalam penggunaan energi.

c. Diadakannya inspeksi bersama, minimal satu kali dalam sebulan guna memonitoring keadaan yang sebenarnya di lapangan.

d. Pengadaan rapat koordinasi untuk membahas pekerjaan yang belum selesai maupun pekerjaan baru.

e. Harus memiliki SOP (Standar Operation Prosedure) untuk digunakan sebagai petunjuk pelaksanaan mutu pekerjaan.

f. Bench Marking, Data operasionil agar didata dan dievaluasi setiap tahun untuk dijadikan bahan acuan atau bench marking seperti:

1) Pemakaian energi listrik $(\mathrm{kWH})$ per meter persegi per bulan atau per tahun.

2) Maintenance cost untuk peralatan utama

3) Waktu yang diperlukan untuk menyelesaikan suatu pekerjaa seperti mengganti lampu.

g. Laporan bulanan berisi total pemakaian energi listrik

\subsection{Bangunan Hijau / Green Building}

Bangunan hijau merupakan bangunan berkelanjutan yang bertanggung jawab terhadap lingkungan dan hemat sumber daya sepanjang siklus hidup bangunan tersebut. Dengan konsep green building ini diharapkan dapat mengurangi penggunaan energi yang berlebih serta dampak polusi sekaligus juga desain bangunan yang ramah lingkungan. Menurut Ervianto (2009), manfaat dari kepemilikan green building [2]:

a. Rendahnya biaya operasional, sebagai akibat efisiensi dalam pemanfaatan energi.

b. Lebih nyaman, dikarenakan suhu dan kelembaban ruang terjaga.

c. Pembangunan wajib memberikan perhatian dalam hal pemilihan material yang relatif sedikit mengandung bahan kimia.

d. Sistem sirkulasi udara yang mampu menciptakan lingkungan dalam ruang yang sehat.

e. Mudah dan murah dalam penggantian berbagai komponen bangunan

f. Biaya perawatan dan perawatannya yang relatif rendah. 


\subsection{Efisiensi dan Konservasi Energi}

Efisiensi energi merupakan pendekatan yang dilakukan melalui pemanfaatan atau pemakaian teknologi yang membutuhkan energi yang lebih rendah dalam melakukan fungsi yang sama seperti penggunaan lampu dan peralatan listrik yang hemat energi [3]. Konservasi energi adalah perilaku yang dapat dilakukan untuk mencapai penghematan energi seperti mematikan lampu dan peralatan elektrik saat tidak digunakan [4]. Kategori ini memiliki 9 kriteria, yang terdiri dari 2 kriteria prasyarat dan 7 kriteria kredit, dimana masing-masing memiliki poin yang terlihat pada Tabel 1 [5] :

Pada hakekatnya IKE ini adalah hasil bagi antara konsumsi energi total selama periode tertentu (satu tahun) dengan luasan bangunan. Satuan IKE adalah $\mathrm{kWH} / \mathrm{m} 2$ per tahun. Persamaan IKE dihitung dengan rumus sebagai berikut :

$$
\begin{aligned}
& \text { IKE }=\frac{P k}{A} \\
& =\frac{\text { Total Konsumsi Energi Listrik (kWH) }}{\text { Luas Bangunan (m2) }}
\end{aligned}
$$

Keterangan :

$\mathrm{IKE}=$ intensitas konsumsi energi $(\mathrm{kWH} / \mathrm{m} 2$ /tahun),

$\mathrm{P}_{\mathrm{K}}=$ konsumsi listrik total $(\mathrm{kWH})$,

$\mathrm{A}=$ luas area $(\mathrm{m} 2)$

Perhitungan konsumsi energi :

$$
W=P \times T
$$

Keterangan :

$\mathrm{W}=$ Konsumsi Energi Listrik (kWh)

$\mathrm{P}=$ Daya Listrik $(\mathrm{kW})$

$\mathrm{T}=$ Waktu Pemakaian (Hour)

\begin{tabular}{|c|c|c|c|}
\hline Kode & Rating & $\begin{array}{l}\text { Poin } \\
\text { Maks }\end{array}$ & Bonus \\
\hline EEC P1 & $\begin{array}{l}\text { Policy and Energy Management } \\
\text { Plan }\end{array}$ & & \\
\hline EEC P2 & $\begin{array}{l}\text { Minimum Building Energy } \\
\text { Performance }\end{array}$ & & \\
\hline EEC 1 & $\begin{array}{l}\text { Optimized Efficiency Building } \\
\text { Energy Performance }\end{array}$ & 16 & \\
\hline EEC 2 & $\begin{array}{l}\text { Testing, Re-commissioning or } \\
\text { Retro-commissioning }\end{array}$ & 2 & \\
\hline EEC 3 & System Energy Performance & 12 & \\
\hline EEC 4 & Energy Monitoring and Control & 3 & \\
\hline EEC 5 & Operation and Maintanance & 3 & \\
\hline EEC 6 & On Site Renewable Energy & & $5 \mathrm{~B}$ \\
\hline EEC 7 & Less Energy Emission & & $3 \mathrm{~B}$ \\
\hline & Total & 36 & \\
\hline & Persentase & $30.77 \%$ & \\
\hline
\end{tabular}

Tabel 1. Kriteria kategori Energy Efficiency and Conservation
Untuk mengetahui besarnya konsumsi energi listrik dihitung dengan persamaan :

$$
B K E L=\mathrm{W} \times T D L
$$

Keterangan :

BKEL = Biaya Konsumsi Energi Listrik

$\mathrm{TDL}=$ Tarif Dasar Listrik

\subsection{Standar Acuan Penilaian}

Penilaian GREENSHIP rating tools untuk bangunan terbangun kriteria Energy Efficiency anda Conservation dapat dilihat pada Tabel 1. Penghematan konsumsi energi pada daya pencahayaan ruangan yang tercantum dalam SNI 03-6197-2000 tetang konservasi energi pada sistem pencahayaan pada Tabel 2.

\subsection{Peningkatan Efisiensi Energi}

Gedung dapat dirancang agar efisien dalam penggunaan energi listrik, dan menekan penggunaan energi yang berlebih. Kunci dari penghematan energi pada gedung adalah melalui perencanaan bentuk bangunan, dengan mengoptimalkan penerangan alami, sehingga penggunaan listrik untuk $\mathrm{AC}$ dan penerangan dapat ditekan serendah mungkin.

Tabel 2. Daya listrik maksimum untuk pencahayaan

\begin{tabular}{lc}
\hline \multicolumn{1}{c}{ Lokasi } & $\begin{array}{c}\text { Daya pencahayaan } \\
\text { maksimum } \\
\text { (W/m2) (termasuk } \\
\text { rugi-rugi balast }\end{array}$ \\
\hline Lembaga pendidikan : & 15 \\
Ruang kelas & 11 \\
Perpustakaan & 13 \\
Laboratorium & 12 \\
Ruang praktek komputer & 13 \\
Ruang laboratorium & \\
bahasa & 12 \\
Ruang guru & 12 \\
Ruang olahraga & 20 \\
Ruang gambar & 8 \\
Kantin & 25 \\
Auditorium & \\
Perkantoran : & 13 \\
Ruang resepsionis & 12 \\
Ruang kerja & 12 \\
Ruang komputer & 12 \\
Ruang rapat & 4 \\
Ruang parkir & 8 \\
Lobi & 7 \\
Ruang makan & 7 \\
Kamar mandi & 10 \\
Area penjualan kecil & 5 \\
Koridor & \\
\hline sumber : SNI 03-6197-2000 &
\end{tabular}




\subsection{Peluang Hemat Energi}

Upaya dalam hemat energi dapat

dilakukan dengan cara :

a. Menekan penggunaan energi dengan cara menggunakan energi seefisien mungkin

b. Mengurangi $\mathrm{kW}$ pada lampu penerangan dan mengatur waktu beroperasi secara optimal

c. Menggunakan sumber energi yang murah atau energi lain selain original emission

\section{METODOLOGI PENELITIAN}

\subsection{Bagan Alur Penelitian}

\section{Gambar 1.}

Bagan alur penelitian ditampilkan pada

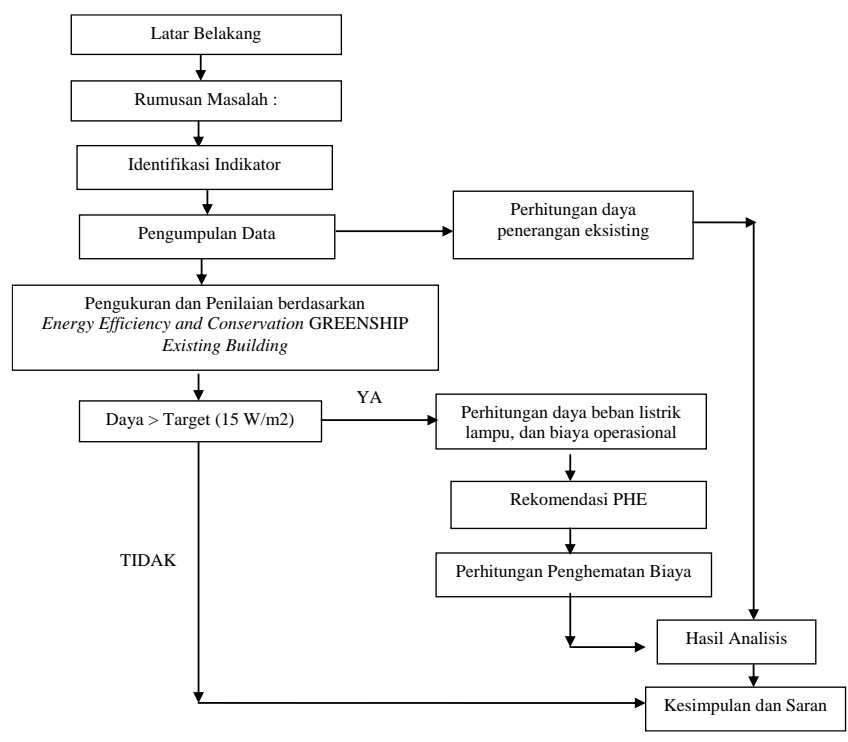

Gambar 1. Bagan alur penelitian

\subsection{Konsep Penlitian}

Penelitian ini berupa evaluasi kinerja efisiensi energi pencahayaan pada gedung $\mathrm{E}$ FIA UB dan perhitungan biaya operasionalnya yang akan dihitung secara teoritis. Proses penelitian melalui pengumpulan data, pengukuran, observasi, dan studi literatur. Pada perhitungan kinerja energi secara teoritis perhitungan dilakukan berdasarkan teori perhitungan konsumsi energi setiap ruangan, dengan menggunakan data gambar gedung $\mathrm{E}$ FIA UB.

\section{HASIL DAN PEMBAHASAN}

\subsection{Obyek Studi}

Bangunan yang dijadikan obyek yaitu bangunan eksisting terdiri dari 8-12 lantai, serta umur bangunan untuk dilakukan penilaian
GREENSHIP Eksisting Building minimal 1 tahun, sehingga obyek yang digunakan adalah Gedung E Fakultas Ilmu Administrasi Universitas Brawijaya yang telah beroperasi kurang lebih selama 1 tahun. Lokasi gedung ini terletak di Jl. Veteran, Malang dekat dengan pintu keluar Jl Soekarno-Hatta. Gedung ini memiliki luas sebesar $12.555,78 \mathrm{~m} 2$ yang terdiri dari lantai semi basement, lantai 1 yang difungsikan untuk kantin,wirausaha mahasiswa, dan bank. Sementara itu, Lantai 2, 3, 4, 5, dan 6 difungsikan untuk ruang kelas perkuliahan. Lantai 7 dikhususkan untuk unit lab.riset. Lantai 8 beberapa ruangan difungsikan sebagai ruang kelas perkuliahan dan ruang unit lab.riset, sedangkan lantai 9 difungsikan untuk pusat kajian pembelajaran jarak jauh. Lantai 10 difungsikan untuk ruang ujian dan mini auditorium, sedangkan lantai 11 difungsikan untuk auditorium.

\subsection{Analisis Kriteria Prasyarat GREENSHIP Rating Tools EB}

Komitmen manajemen merupakan hal mendasar yang dibutuhkan dalam rangka mewujudkan lingkungan binaan yang sehat dan ramah lingkungan. Terlebih pada bangunan pendidikan yang membutuhkan suasana yang kondusif dan representatif untuk mendukung kegiatan belajar mengajar. Penilaian kriteria prasyarat dalam GREENSHIP EB ini bertujuan untuk mengetahui sejauh mana kriteria ini dapat diterapkan.

Pada kriteria ini dilakukan penilaian yang menitikberatkan pada konsumsi energi listrik dalam gedung serta kegiatan peningkatan kinerja pencahayaan lampu dan sistem lain dalam gedung yang didukung oleh dokumen atau pencatatan rutin bulanan. Seperti halnya gedung lain dalam kawasan kampus Universitas Brawijaya, sistem pencatatan listrik terpusat di gedung Rektorat.

Gedung E FIA UB belum menggunakan sumber energi terbarukan, masih menggunakan satu sumber energi yaitu original emission (PLN). Dari hasil penilaian Greenship rating tools pada Gedung E FIA UB pada Tabel 3 terlihat untuk kriteria efisiensi dan konservasi energi ini masih belum memenuhi standar dengan poin 19, dengan IKE pada gedung E FIA UB yaitu :

$$
I K E=\frac{P k}{A}
$$


$=\frac{761.560}{12.555,78}=60,65 \mathrm{kWH} / \mathrm{m} 2 /$ tahun

Nilai IKE dalam setahun ini lebih kecil dari IKE listrik standar, yaitu sekitar 60,65 $\mathrm{kWH} / \mathrm{m} 2 /$ tahun, masih dalam kategori efisien, namun masih bisa dilakukan penghematan yang lebih besar, sehingga kriteria EEC 1 diberi poin 9. Kriteria EEC 2 tentang komisioning, pengujian pada gedung E FIA UB hanya dilakukan sekali pengujian/komisioning pada awal penggunaan sehingga diberi 1 poin. Untuk kriteria EEC 3 sistem kinerja energi, beberapa ruangan telah menggunakan daya lampu sesuai dengan standar dan menggunakan LED, untuk penggunaan $\mathrm{AC}$ telah menggunakan air cooled dan split, sehingga mendapatkan poin 6 . Kriteria EEC 4 adanya kWH meter untuk beberapa sistem listrik dan penggunaan display energy di tempat publik sehingga mendapatkan 2 poin. Kriteria EEC 5 mendapatkan 1 poin untuk sub kriteria panduan pengoperasian alat-alat. Sedangkan EEC 6 dan EEC 7 mendapatkan 0 poin karena belum adanya penggunaan energi terbarukan dan pengurangan emisi energi.

\subsection{Analisis Konsumsi Energi Eksisting}

Untuk analisis konsumsi energi listrik dalam pengggunaan pencahayaan, didapatkan besar beban listrik pencahayaan dengan berdasarkan penggunaan ruangan yang sesuai dengan pengamatan di lapangan. Total beban daya pencahayaan dalam waktu sehari

- (LWBP) yaitu 163,282 kW/hari

- (WBP) yaitu $140,177 \mathrm{~kW} / \mathrm{hari}$.

Kemudian hasil beban per hari dikalikan dengan jumlah hari efektif dalam satu minggu terdapat 5 hari efektif sehingga dalam satu bulan terdapat 20 hari efektif, sehingga perhitungan beban energi pencahayaan dalam satu bulan adalah

- Beban LWBP $=163,282 \mathrm{~kW} / \mathrm{hari} \quad \mathrm{x} 20$ hari $=3.265,646 \mathrm{kWH} / \mathrm{bulan}$

- Beban WBP = 140,177 kW/hari x 20 hari $=2.803,534 \mathrm{kWH} / \mathrm{bulan}$

- Sehingga total daya konsumsi energi = $6.069,2 \mathrm{kWH} / \mathrm{bulan}$,

\subsection{Analisis Biaya Energi Perncahayaan Operasional Eksisting}

Analisis biaya energi listrik dalam pengggunaan pencahayaan bahwa TDL (tarif dasar listrik) pada gedung E Fakultas Ilmu
Tabel 3. Penilaian greenship pada Gedung E FIA UB

\begin{tabular}{lc}
\hline \multicolumn{1}{c}{ Kode - Kriteria } & Nilai \\
\hline EEC 1 - Optimasi Kinerja Efisiensi Energi & 9 \\
Bangunan & \\
EEC 2 - Pengujian, Komisioning ulang, & 1 \\
atau retrokomisioning & \\
EEC 3 - Kinerja Sistem Energi & 6 \\
EEC 4 - Monitoring dan Kontrol Energi & 2 \\
EEC 5 - Operasional dan Pemeliharaan & 1 \\
EEC 6 - Penggunaan Energi Terbarukan & 0 \\
EEC 7 - Pengurangan Emisi Energi & 0 \\
Total & 19 \\
\hline
\end{tabular}

Hasil Analisis, 2018

Administrasi Universitas Brawijaya, universitas termasuk golongan S3, dengan harga tarif LWBP Rp.735- dan WBP Rp. 1.102,-. Perhitungan beban penggunaan daya listrik pencahayaan lampu pemakaian LWBP dan WBP, sehingga untuk perhitungan biaya, yaitu

$\mathrm{BKEL}_{(\mathrm{LWBP})}=\mathrm{W} \times \mathrm{TDL}$ $=3.265,646 \mathrm{kWH} / \mathrm{bulan} \times \mathrm{Rp} .735$ $=$ Rp. $2.400 .250,-$

$\mathrm{BKEL}_{(\mathrm{WBP})}=\mathrm{W} \times \mathrm{TDL}$ $=2.803,534 \mathrm{kWH} /$ bulan $\mathrm{x}$ Rp. 1.102 $=$ Rp. 3.089.494,-

BKEL total $=$ BKEL $_{(\mathrm{LWBP})}+\mathrm{BKEL}_{(\mathrm{WBP})}$ $=$ Rp. 2.400.250,- + Rp. 3.089.494,$=$ Rp. 5.489.744,-

Total biaya konsumsi energi listrik eksisting untuk biaya daya listrik pencahayaan sebesaar Rp. 5.489.744,-

\subsection{Analisis Perbandingan Kapasitas Daya Pencahayaan Eksisting}

Sistem pencahayaan eksisting pada gedung E FIA UB menggunakan bermacam-macam tipe, seperti pada Tabel 4

Setelah dihitung kapasitas daya masing masing ruang dan disesuaikan dengan luasan ruangan; terdapat beberapa ruangan yang melebihi standar SNI daya maksimum per ruangan, dan dapat diringkas pada Tabel 5.

\subsection{Analisis Peluang Hemat Energi}

Berdasarkan data beban listrik pencahayaan dan biaya operasional eksisting, dapat diketahui langkah selanjutnya dalam proses penghematan energi listrik pada pencahayaan, dengan manajemen biaya dapat 
mengatur pengeluaran biaya operasional dengan merekomendasikan peluang hemat energi, yaitu:

Tabel 4. Pencahayaan eksisting Gedung E FIA UB

\begin{tabular}{lc}
\hline \multicolumn{1}{c}{ Type } & watt \\
\hline Lampu TL TKO Surface Mounted & $1 \times 36$ \\
Lampu TL V-Shape & $1 \times 36$ \\
Wall Mounted cover acrilic & $1 \times 36$ \\
Lampu RCM TKI & $2 \times 36$ \\
Lampu RCM TKI + Battery & $2 \times 36$ \\
Lampu downlight PLC & 18 \\
Lampu downlight PLC + Battery & 18 \\
Lampu downlight PLC & 13 \\
\hline Data eksiting,2018 &
\end{tabular}

Tabel 5. Ruangan yang melebihi standart maksimum

\begin{tabular}{lc}
\hline \multicolumn{1}{c}{ Ruang } & watt \\
\hline Ruang Perkuliahan E.6.4 & 18,01 \\
Ruang Perkuliahan E.6.5 & 18,01 \\
Lab riset 3 lantai 7 & 18,01 \\
Lab riset 4 lantai 7 & 18,01 \\
Ruang seminar lantai 8 & 15,29 \\
Ruang seminar/ruang rapat lantai 8 & 15,29 \\
Pusat kajian 2 lantai 9 & 14,08 \\
Pusat kajian 3 lantai 9 & 14,08 \\
Pusat kajian 6 lantai 9 & 16,19 \\
Pusat kajian 7 lantai 9 & 15,48 \\
Pembelajaran jarak jauh lantai 9 & 12,14 \\
Ruang ujian 1 lantai 10 & 16,53 \\
Ruang ujian 4 lantai 10 & 16,19 \\
Ruang admin lantai 10 & 15,45 \\
Hasil analisis,2018 &
\end{tabular}

\subsubsection{Peluang Hemat Energi Strategi 1}

Potensi penghematan energi pada sistem pencahayaan yang memiliki intensitas daya maksimum yaitu dengan penggantian lampu TL/PLC ke lampu yang lebih hemat energi, yaitu LED. Keunggulan dari lampu LED yaitu lampu hemat energi dalam konsumsi energi dan juga lebih tahan lama karena memiliki lifetime /umur pemakaian selama 40.000 jam beroperasi menurut SNI 6197 : 2011. Daya dan light output lampu LED jika dibandingkan dengan Fluorescent.

$$
\begin{gathered}
\mathrm{F}_{\text {total }}=\frac{E x \boldsymbol{A}}{\boldsymbol{K}_{p} \times \boldsymbol{K}_{d}} \text { (lumen) } \\
\text { Ftotal }=\frac{(250.31,98)}{0,7 \times 0,5} \\
=22.842,8571 \text { lumen }
\end{gathered}
$$

Perhitungan kebutuhan lumen dengan menggunakan sample untuk ruangan perkuliahan di lantai 6 , yang awalnya menggunakan lampu TL 2 x36 watt, setelah di hitung ulang dengan perhitungan kebutuhan lumen dalam ruangan sebesar 22.842, 8571 lumen dengan luasan raungan $31,98 \mathrm{~m} 2$ dan standart intensitas cahaya sebesar 250 lux, yang kemudian dibagi dengan koefisien standar penggunaan dan penyusutan. Kemudian dilanjutkan dengan perhitungan banyaknya lampu yang dibutuhkan jika dalam satu armatur terdapat dua lampu, lumen lampu yang digunakan adalah lumen lampu LED karena Lampu LED merupakan lampu yang hemat energi, dengan watt lebih kecil tetapi dapat menghasilkan lumen yang besar. Asumsi yang digunakan adalah LED 16 watt sebanyak 2 buah dalam satu armatur.

$$
\begin{gathered}
\mathrm{N}_{\text {total }}=\frac{\boldsymbol{F}_{\text {total }}}{\boldsymbol{F}_{1} \boldsymbol{x} \boldsymbol{n}} \\
\begin{aligned}
\text { Ntotal } & =\frac{22.842,8571}{1600 \times 2}=7,13 \text { lampu } \\
& =8 \text { lampu }
\end{aligned}
\end{gathered}
$$

Dari hasil tersebut lampu TL yang digunakan dapat diganti dengan lampu TL LED dengan kapasitas 2x16 watt dengan menggunakan armatur yang sudah tersedia. Pengheatan daya lampu bisa hemat sampai 40 watt setiap armaturnya, rata-rata jumlah armatur setiap ruangan perkuliahan sebanyak 8 buah dengan kapasitas 2 lampu.

Lampu eksisting dengan daya 2x36 watt sejumlah 531 buah :

$$
\begin{gathered}
\Sigma \mathrm{P}(\text { eksisting })=\text { Daya } \times \text { jumlah lampu }= \\
2 \times 36 \times 531=38.232 \text { Watt }
\end{gathered}
$$

Setelah dilakukan pengurangan daya lampu menjadi 2 x 16 watt, maka perhitungannya sebagai berikut:

$\Sigma \mathrm{P}($ rekomendasi $)=$ Daya $\mathrm{x}$ jumlah lampu $=$ $2 \times 16 \times 531=16.992$ Watt

Selisih daya lampu dari 38.232 watt dengan 16.992 watt, sebesar 21.240 watt atau 21,24 kW. Diasumsikan pada saat luar waktu beban puncak (LWBP) digunakan selama 4 jam dengan prosentase penggunaan $50 \%$, . $\Sigma \mathrm{P}=21,24 \mathrm{~kW} \times 4$ jam $\times 50 \%=42,48 \mathrm{kWH}$

Kemudian akan dikalikan banyaknya hari efektif yaitu 5 hari sehingga dalam sebulan terdapat 20 hari. 


$$
\begin{aligned}
\Sigma \mathrm{P}= & 42,48 \mathrm{kWH} \times 20 \text { hari }=849,6 \mathrm{kWH} / \text { bulan } \\
& \text { BKEL }{ }_{(\mathrm{LWBP})}=\mathrm{W} \times \mathrm{TDL} \\
= & 849,6 \mathrm{kWH} \times \mathrm{Rp} .735=\text { Rp. } 624.456,-
\end{aligned}
$$

Pada saat waktu beban puncak (WBP) diasumsikan digunakan selama 4 jam dengan prosentase penggunaan $70 \%$, Pada saat beban puncak (WBP) Penghematan energi yang didapat :

$\Sigma \mathrm{P}=21,24 \mathrm{~kW} \times 4 \mathrm{jam} \times 70 \%=59,472 \mathrm{kWH}$

Kemudian akan dikalikan banyaknya hari efektif yaitu 5 hari sehingga dalam sebulan terdapat 20 hari.

$\Sigma \mathrm{P}=59,472 \mathrm{kWH} \times 20$ hari $=1.189,44$ $\mathrm{kWH} / \mathrm{bulan}$

$$
\begin{aligned}
\operatorname{BKEL}_{(\text {WBP })} & =\Sigma \mathrm{P} \times \mathrm{TDL} \\
& =1.189,44 \mathrm{kWH} \times \mathrm{Rp} .1 .102,- \\
& =\text { Rp. } 1.310 .762,88
\end{aligned}
$$

Dari perhitungan di atas penghematan daya yang dihasilkan, yaitu menghemat daya sebesar :

$849,6 \mathrm{kWH} / \mathrm{bulan}+1.189,44 \mathrm{kWH} / \mathrm{bulan}$ $=2.039,04 \mathrm{kWH} / \mathrm{bulan}$

Sehingga total penghematan biaya LWBP dan WBP sebesar :

$\mathrm{BKEL}_{(\mathrm{LWBP})}+\mathrm{BKEL}_{(\mathrm{WBP})}$

$=$ Rp. 624.456,- + Rp. 1.310.762,88

$=$ Rp. 1.935.218,88/bulan

Perincian potensi penghematan / konservasi energi pada sistem pencahayaan yaitu penggantian lampu TL menjadi lampu LED, dengan rincian sebagai berikut :

- Penggunaan lampu TL eksisting dengan total daya lampu $38,232 \mathrm{~kW}$

- Lama beroperasi adalah 8 jam

- frekuensi beroperasi sekitar $70 \%$

- 5 hari masa efektif atau 20 hari dalam sebulan

- Penghematan daya $51.383,808 \mathrm{kWH} / \mathrm{tahun}$

- Penghematan biaya Rp. 94.392.055,-

- Biaya penggantian LED 2x16 watt, dengan jumlah lampu 531 buah

- Penghematan energi per lampu sampai 40 watt,

- Penghematan energi sebesar 2.039,04 $\mathrm{kWH} / \mathrm{bulan}$ dan per tahun sebesar $24.468,48 \mathrm{kWH} /$ tahun
- total penghematan biaya sebesar Rp. 23.222.626,-.

- biaya investasi pembelian lampu TL LED merk Phillips 2x16 w dengan harga Rp. 47.000 sebanyak 531 buah, = Rp. 24.957.000,-

- periode pengembalian modal atau pay back selama 1,07 tahun.

\subsubsection{Peluang Hemat Energi Strategi 2}

Potensi penghematan energi pada sistem pencahayaan dengan mengurangi waktu konsumsi energi pada ruang perkuliahan dan ruang lab riset. Untuk pengurangan waktu operasional dibatasi sampai jam 19.00 yang biasanya beroperasi sampai jam 21.00, sehingga dapat menghemat biaya WBP selama 2 jam. Beban daya ruang kelas perkuliahan untuk 2 lantai yaitu lantai 2 dan 3 serta ruang lab riset di lantai 7, yaitu

$$
\Sigma \mathrm{P}=12,506 \mathrm{~kW}+4,921 \mathrm{~kW}=17,427 \mathrm{~kW}
$$

Penghematan daya pada skenario ini saat WBP, yaitu

$$
17,427 \mathrm{~kW} \text { x } 2 \text { jam }=34,854 \mathrm{kWH}
$$

Penghematan biaya saat WBP sebesar

$$
\text { 34,854 kWH x Rp. } 1.102=\text { Rp. 38.409,- }
$$

Jika dalam sebulan dapat menghemat sekitar 777,08 kWH/bulan dengan menghemat biaya dalam sebulan sebesar Rp. 768.182,- sehingga per tahun akan menghemat Rp. 9.218.185,- dengan menghemat beban daya 9.324,96 $\mathrm{kWH} /$ tahun.

\subsubsection{Rekomendasi Alat Hemat Energi}

Penghematan energi berikutnya pada sistem pencahayaan buatan adalah dengan menggunakan beberapa alat :

a. Sensor gerak pada beberapa tempat yang hanya digunakan tidak begitu lama yaitu pada area koridor, area tangga darurat. Sensor gerak ini dapat menjangkau pergerakan sepanjang 4-8 meter dengan detection angle hingga 360 derajat, dan akan otomatis lampu akan mati setelah 30 detik atau bisa diatur untuk pengontrolan cahaya dan waktu menyala selama ada 
pergerakan. Lampu yang digunakan mampu sampai LED 30 watt.

b. Penggunaan Dimmer pencahayaan si bebera ruang perkuliahan dan lab riset, dikarenakan dapat diatur besar kecilnya pencahayaan yang terpasang.

c. Penggunaan energi lain dari PLN yaitu penggunaan solar cel.

\section{KESIMPULAN DAN SARAN}

\subsection{Kesimpulan}

Berdasarkan hasil dan pembahsan dapat ditarik kesimpulan :

a. Bedasarkan penilaian GREENSHIP bahwa pada Gedung E Fakultas Ilmu Administrasi Universitas Brawijaya mendapatkan 19 poin dari 36 poin standar $\quad(16,7 \%$ dari $30,77 \%)$, disimpulkan bahwa gedung tersebut tidak memenuhi poin standar. Perhitungan IKE selama setahun sebesar $60,65 \mathrm{kWH} / \mathrm{m} 2 /$ tahun, termasuk kategori efisien. Jika SOP dan dokumen pendataan rutin hasil pantau $\mathrm{kWHmeter,}$ serta terdapat energi selain original emission maka poin untuk Greenship dapat terpenuhi dalam kriteria efisiensi dan konservasi energi

b. Beberapa ruang melebihi batas daya maksimum berdasarkan SNI, yaitu ruang perkuliahan di lantai 6 , lab riset di lantai 7 , ruang seminar lantai 8 , ruang ujian lantai 10, dan ruang admin lantai 10.

c. Biaya operasional eksisting penggunaan daya lampu sebesar Rp. 5.489.744,dalam sebulan dengan total daya konsumsi 6.069,2 kWH/bulan

d. Efisiensi penggunaan biaya operasional perlu sistem manajemen biaya yang mengatur perencanaan, pelaksanaan, dan pengendalian.

- Pengurangan daya lampu dilakukan menjadi 2 x16 watt penghematan yang didapat sekitar 2.039,04 kWH/bulan dan Rp. 1.935.218,88 / bulan, sehingga penghematan sekitar 35\%

- Pengurangan waktu konsumsi lampu pada WBP dengan selisih 2 jam dari waktu, penghematan yang di dapat sebesar Rp. 768.182,- dengan menghemat beban daya 777,08 $\mathrm{kWH} /$ tahun.

e. Rekomendasi hemat energi dengan menggunakan alat sensor gerak, penggunaan dimmer, dan penggunaan energi solar cell dapat mencapai $20 \%$ penghematan

\subsection{Saran}

Adapun saran berdasarkan hasil dan pembahasan :

a. Data-data dalam penelitain ini sebagian menggunakan asumsi berdasarkan aktivitas dan kondisi di lapangan, dikarenakan gedung belum optimal beroperasi.

b. Diperlukan simulasi menggunakan software Ecotect untuk menganalisis sistem pencahayaan dan simulasi penerapan nya.

c. Pengelola dapat mengatur manajemen operasional gedung sehingga manajemen biaya yang tepat akan menghasilkan penghematan biaya dan energi yang optimal.

\section{DAFTAR PUSTAKA}

[1] Donald S. Barrie, Boyd Paulson dan Sudinarto, "Manajemen Konstruksi Profesional", Erlangga, Jakarta, 1990

[2] Ervianto. Wulfram I. 2009. Manajemen Proyek Konstruksi. Jakarta: Penerbit Graha Ilmu

[3] Badan Standardisasi Nasional. 2001. Tata Cara Perancangan Sistem Pencahayaan Buatan Pada Bangunan Gedung. Jakarta. . SNI 03-6575-2001

[4] Badan Standarisasi Nasional. 2011. Konservasi energi pada sistem pencahayaan. SNI 03-6197-2011.

[5]Green Building Council Indonesia. 2016. Greenship Rating Tools. (online) http://www.gbcindonesia.org . Diakses pada tanggal diakses 1 September 2017 